DOI: 10.17707/AgricultForest.64.1.01

\author{
Radovan KASARDA, \\ Nina MORAVČÍKOVA, Ondrej KADLEČÍK ${ }^{1}$
}

\title{
GENETIC STRUCTURE OF WARMBLOOD HORSES ON MOLECULAR-GENETIC LEVEL
}

\begin{abstract}
SUMMARY
The aim of this study was to evaluate the genetic structure and potential loss of diversity within three horse breeds: Lipizzan (42), Furioso (38), and Nonius (18) on molecular-genetic level. The genotyping data were obtained from in total 98 individuals presenting the genepool of analysed breeds in Slovakia. The values of gene diversity $(0.72)$ as well as heterozygosity $(0.89)$ showed the prevalence of heterozygotes within each population. The negative value of $F_{\text {IS }}$ index $(-0.25)$ pointed, in particular, to good level of diversity and balanced proportion of homozygous and heterozygous animals in populations, i.e. HWE equilibrium. The Shannon's information index (I=1.41) confirmed sufficient level of variability mainly in order to maintain the current state of biodiversity for future generation. The genetic distances on intra- and inter-population level revealed clearly distribution of individuals into the three separate genetic clusters. The highest genetic similarity was found between Nonius and Furioso breeds $(\mathrm{DA}=0.16)$. However, the pairwise $\mathrm{F}_{\mathrm{ST}}$ values and PCA analysis were not fully sensitive to detect the genetic differences among those breeds. We were able to detect only two genetic clusters, when Furioso and Nonius were linked together. This can be explained mainly by the use of English Thoroughbreds stallions and mares in building up process of both breeds. Considering that the results related to the state of diversity in presented breeds are correct, they can be used as basis for the further progress in breeding programs which is necessary to prevent the loss of heterozygosity and increase of inbreeding.
\end{abstract}

Keywords: AnGR, diversity, genetic differentiation, horse breeding, microsatellites variability.

\section{INTRODUCTION}

Changes of conditions in production systems as well as significant competition among breeds create expectation of risk, which will negatively influence surviving of livestock species including horses. Within this context some breeds strengthen their position and expanded to different countries, while others, not based on commercialization, started to decrease their number and become endangered (Kadlečík and Kasarda, 2014).

\footnotetext{
${ }^{1}$ Radovan Kasarda, (corresponding author: radovan.kasarda@uniag.sk), Nina Moravčíková, Ondrej Kadlečík, Department of Animal Genetics and Breeding Biology, Slovak University of Agriculture in Nitra, SLOVAKIA

Paper presented at the $8^{\text {th }}$ International Scientific Agricultural Symposium "AGROSYM 2017".

Notes: The authors declare that they have no conflicts of interest. Authorship Form signed online.
} 
In recent years, a slight increase of the global equine population size has been recorded. The world's equine population is estimated at 65 million according to the Food and Agriculture Organization of the United Nations (FAOSTAT). Unfortunately, this positive trend of population size so completely does not apply in Slovakia. The horse breeding and its improvement in our region was negatively influenced mainly by privatization mostly followed by bankruptcy of purebred animals breeding in stud farms in the nineties. Currently, the horse population reach total number around 16,600 only, placing the Slovak Republic to the last position in the horse population size in the middle European region. The development of particular populations in Slovakia is affected mainly by the decline in mares' proportion and also due to negative changes in population age structure (Halo et al., 2008; Zöldág, 2008; Buleca et al., 2010).

Despite the low effective population size the horse breed variability is colourful. Lisáková (2009) indicates that in the 2008 11,068 horses of 27 different breeds were bred in Slovakia. But given the current state across warmblood horses in Slovakia, populations of Furioso (number of active breeding horses in Stud book on the level 30 stallions and 180 mares, while in reproduction is involved only 60 mares) and Lipizzan (with total number of mares 80 and number of stallions 13) breeds are considered as endangered by the loss of genetic diversity. In addition, population of Nonius horses with total number of active stallions on level 8 and 110 mares (but only 30 is reproductive active) is regarded as critically endangered (ZCHKS, 2017). Mainly for this reason, the Ministry of Agriculture of the Slovak Republic is planning to increase support of the horse breeding namely in the branches of draught work in agriculture and forestry including agrotourism and also in sport utilization in horse riding and hipotherapy. In the reaction to the changes in social and political systems the state of "certified breeding organization" in the area of horse breeding only 3 organizations were assigned by Ministry of Agriculture: Slovak Horse Breeding Association, National Stud in Topol'čianky and Turf Directory in Bratislava (Buleca et al., 2010).

The analysis of genetic diversity as well as the loss of heterozygosity of horse populations in Slovakia have been evaluated mainly based on the pedigree data (Pjontek et al., 2010; Hazuchová et al., 2013). However, the current availability of different type of genetic markers allows more precise examination compared to pedigree analysis and offer advantages that are particularly appropriate for future conservation of AnGR (Petersen et al. 2013). One of the most commonly used markers are microsatellite loci. Genetic characterization based on microsatellites analysis proved to be a reliable tool to quantify genetic variation within and among breeds thereby contributing to the orientation of conservation strategies (Rukavina et al., 2015).

The aim of this study was to analyse genetic structure of populations and degree of diversity loss within three horse breeds (Lipizzan, Furioso, and Nonius) that belong currently to most endangered warmblood horse populations in Slovakia. 


\section{MATERIAL AND METHODS}

The genetic variability was evaluated on both intra- and inter-population levels based on the genotyping data that was collected from a total of 98 individuals presenting the genepool of three breeds: Lipizzan $(\mathrm{N}=42)$, Furioso $(\mathrm{N}=38)$, and Nonius $(\mathrm{N}=18)$ in Slovakia. The genotype database of individuals was prepared by using overall 13 microsatellite systems (AHT4, AHT5, ASB2, HMS1, HMS2, HMS3, HMS6, HMS7, HTG10, HTG4, HTG6, HTG7, and VHL20), routinely used for paternity testing.

The potential loss of genetic diversity within breeds was measured based on following parameters: mean number of alleles (MNA), effective allele number $\left(N_{e}\right)$, observed heterozygosity $\left(H_{o}\right)$, expected heterozygosity mostly referred to as gene diversity $\left(H_{e}\right)$, and Shannon's index $(I)$ using the Genalex version 6.1 (Peakall and Smouse, 2012). The significance of HWE departure (HardyWeinberg equilibrium) reflecting the differences between observed and expected genotype frequencies were tested by Chi-square test. The amount of inbreedinglike effect within population $\left(F_{I T}\right.$ or $\left.F\right)$, among individuals in population $\left(F_{I S}\right.$ or $f$ ), and among individuals within subpopulations $\left(F_{S T}\right.$ or $\left.\theta\right)$ was measured according to the method described by Weir and Cockerham (1984) using FSTAT software (Goudet, 2002).

The hierarchical distribution of molecular variance was tested by ANOVA statistical model implemented in the Arlequin v3.5 (Excoffier et al., 2005). An analysis of molecular variance was performed using 10,000 permutations. The genetic differentiation were calculated on inter-population level based on Wright's $F_{\text {ST }}$ index and on intra-population level by using Nei's standard distance noted as $\mathrm{D}_{\mathrm{A}}$ (Nei et al., 1983). Nei's $\mathrm{D}_{\mathrm{A}}$ distance assumes that the differentiation arises due to mutations and genetic drift. It is known that this indices give more reliable results particularly for microsatellite data. The population genetic structure was tested based on the principal component analysis (PCA) using implemented in R package adegenet 1.3-0 (Jombart and Ahmed, 2011).

\section{RESULTS AND DISCUSSION}

Generally, in view of AnGR conservation proportion of genetic diversity within each of analysed populations can be regarded as sustainable and reflecting only slight loss of total genetic variability. Significant differences indicated potential loss of variability within populations was found only between mean number of allele (5.231 \pm 0.426$)$ and effective allele number $(4.007 \pm 0.299)$. But the proportion of alleles with frequency higher than 0.05 was comparable with observed effective allele numbers (Fig. 1). The number of private alleles characterizing genetic uniqueness of analysed breeds ranged from 0.385 (Nonius) to 0.923 (Furioso) that signalized only relative low degree of genetic differentiation across analysed populations. Expected heterozygosity in range from 0.650 (Lipizzan) to 0.755 (Furioso) indicated sufficient proportion of heterozygote individuals. Similarly Wright's $F_{I S}$ index confirmed higher proportion of heterozygotes in each population $(-0.246 \pm 0.032)$. The Shannon's 
information index $(1.41 \pm 0.049)$ confirmed sufficient level of variability mainly in order to maintain the current state of biodiversity for future generation (Fig. 1). The obtained level of genetic diversity within breeds is comparable to the results found in other warmblood horses, including for example Haflinger (Vostrý et al., 2015) or Old Kladruber horses (Kasarda et al., 2016).

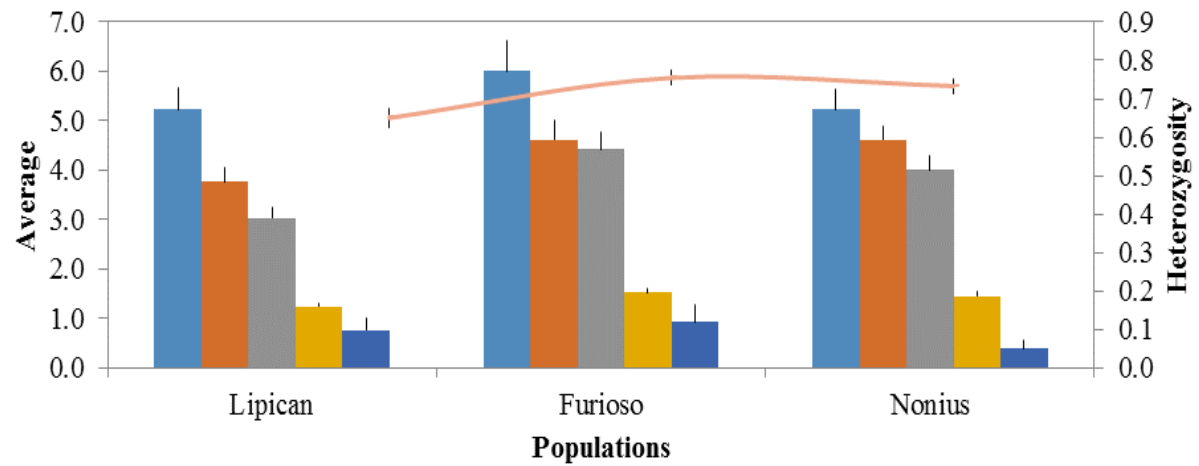

$=\mathrm{Na}=\mathrm{Na}$ Freq. $>=5 \%=\mathrm{Ne}=\mathrm{I}=$ No. Private Alleles $-\mathrm{He}$

Figure 1. Allelic pattern across populations.

The principal component analysis was performed to describe the highest proportion of variance in dataset. The retained 96 PCA axes in analysis corresponded to more than $90 \%$ of conserved variance within metapopulation. The highest proportion of variance was explained by first two principal components that were subsequently used to visualization of genetic relationship among individuals (Fig. 2).

Based on first principal component we were able to describe $2.33 \%$ of variance and second component represented overall 1.13\% of variance. Figure 2 clearly shows the division of individuals into the clusters according their origin mainly with respect to historical development of each breed. As we can see on the Figure 2 Nonius and Furioso populations were linked together, whereas Lipizzan horses formed separate cluster. In case of Nonius and Furioso populations this indicated higher degree of genetic similarity between them that was also proved by Nei's genetic distances and $F_{S T}$ index.

The matrix constructed based on Nei's genetic distance showed that the populations of Nonius and Furioso can be regarded as genetically more similar than any other pair-wise comparison with Lipizzan $\left(D_{a}=0,164\right)$. The highest genetic distance was observed between Lipizzan and Nonius populations $\left(D_{a}=0,336\right)$. On the individual level the genetic distance matrix revealed three separate clusters. Figure 3 shows distribution of individuals into clusters reflecting genetic background of each breed. Based on this we can conclude that the Nei's approach was more sensitive to analysis of genetic relationship within and between horse populations than PCA analysis. 


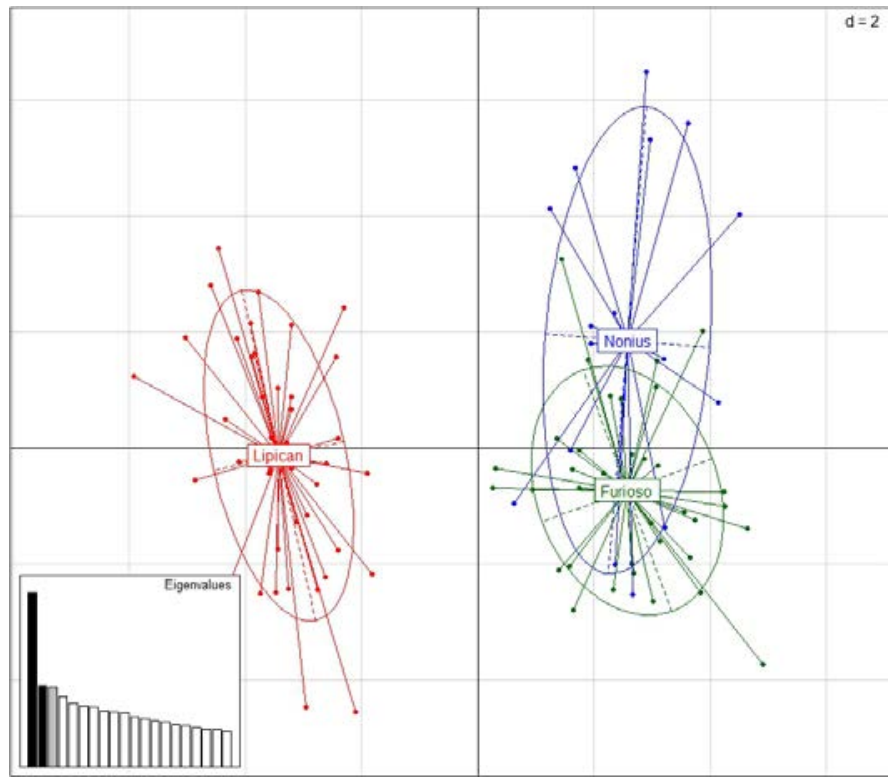

Figure 2. Genetic structure of population based on PCA analysis.

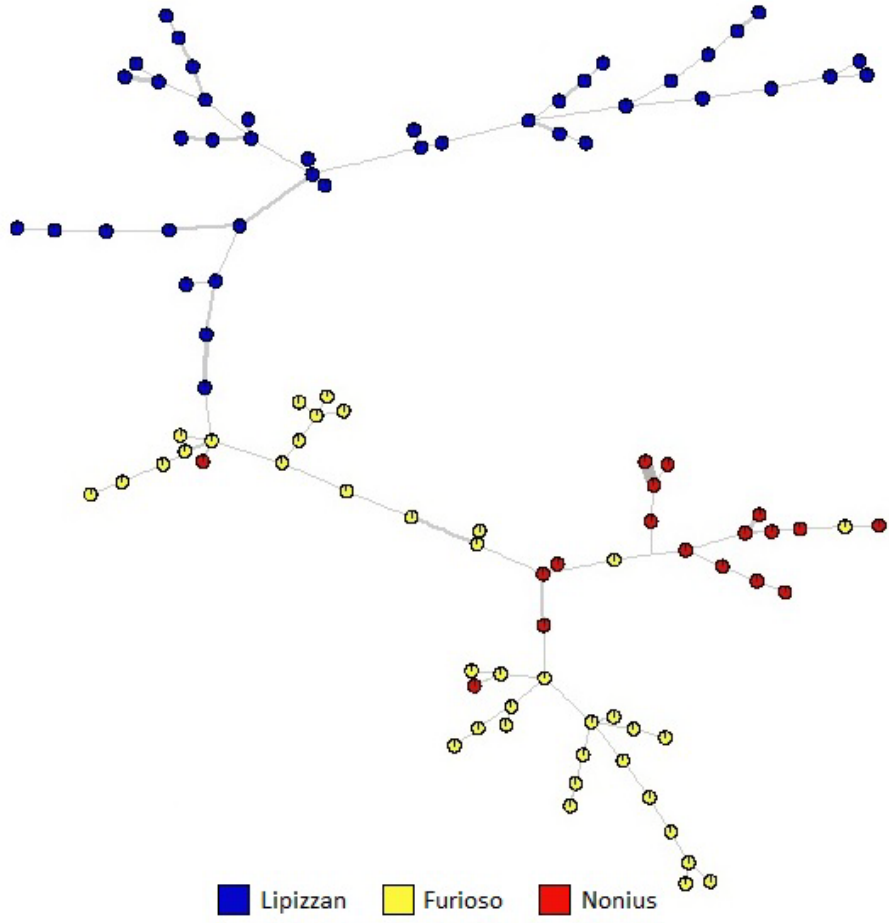

Figure 3. Population structure presenting relationship among individuals based on Nei's Da genetic distances. 
One of the reasons can be relatively small sample size of Nonius population as well as the proportion of missing data. This bias can be reduces by applying approaches that utilize also correction for sample size. On the other hand more logically explanation of our results is fact that the Nonius and Furioso breeds have common historical origin. Both of breeds have been bred in Mezöhegyes Stud Farm. In the founder population of Nonius breed the maternal lines was created by using mares of Spanish-Neapolitan origin and characteristic of these mares are still evident in the breed today. The progenitor of the Nonius breed was an Anglo-Norman stallion Nonius senior (Lukáć, 2010). Later, to correct faults that had manifested in the Nonius breed, blood of English Thoroughbreds was used. The Furioso horses were created by using foundations sires Furioso (English Thoroughbred stallion) and North Star. The mares were mostly Nonius. Furioso have been also crossed by other English Thoroughbreds stallions to produce animals highly qualified for sporting purposes (ZCHKS, 2017).

\section{CONCLUSIONS}

Development of molecular genetic techniques provides now opportunity for increase of selection strategies and livestock breeding. The spectrum of genetic markers utilization including microsatellites is huge and is still expanding. The microsatellites are widely used particularly in genome mapping, phylogenetic studies, forensic analyses, genotyping of individuals in population, determination of paternity, estimation of effective population size a population structure, and analysis of genetic diversity.

Considering that the results related to the state of diversity in presented breeds are correct, they can be used as basis for the further progress in breeding programs which is necessary to prevent the loss of heterozygosity and increase of inbreeding. Conservation of AnGR diversity allows to protect its as cultural heritage for future generation.

\section{ACKNOWLEDGEMENT}

This study was supported by the Slovak Research and Development Agency (APVV-14-0054) and VEGA (1/0742/17). The genotyping data was provided by the Breeding Services of the Slovak Republic (PSSR). With this we would like to acknowledge Ing. L. Neupane Mlyneková, PhD. and Ing. S. Mindeková, $\mathrm{PhD}$. for their cooperation in data preparation.

\section{REFERENCES}

Buleca, J. Jr., Valocký, I., Karahuta, Š., Buleca, J., Takáčová, D. (2010). Gene reserves characteristics and risk populations identification in Slovak horses. Stočarstvo, 64, $101-105$.

Excoffier, L., Laval, G., Schneider, S. (2005). Arlequin ver. 3.0: An integrated software package for population genetics data analysis, Evolutionary Bioinformatics Online, 1, 47 - 50. 
Goudet, J. (2002). FSTAT Computer Package for PCs. Institute of Ecology, Lausanne, Switzerland.

Halo, M., Strapák, P., Hollý, A., Mlyneková, E., Kovalčík, E., Horný, M. (2008). Influence stress on the training process of the horses. Central European Journal of Agriculture, 9, 217 - 224.

Hazuchová, E., Kasarda, R., Kadlečík, O., Pavlík, I., Žitný, J., Moravčíková, N., Horný, M. (2013). Assessment of genetic diversity and analysis of pedigree completeness in three horse breeds in Slovakia. Archiva Zootechnica, 16, 5 - 14.

Jombart, T., Ahmed, I. (2011). Adegenet 1.3-1: new tools for the analysis of genomewide SNP data. Bioinformatics, 1, 3070 - 3071.

Kadlečík, O., Kasarda R. (2014). Genetic diversity of Slovak Sport Pony based on genealogical information. Book of abstracts of the 65th annual meeting of the European federation of animal science, Copenhagen, Denmark.

Kasarda, R., Vostrý, L., Moravčíková, N., Vostrá Vydrová, H., Dovč, P., Kadlečík, O. (2016). Detailed insight into genetic diversity of the Old Kladruber horse substructure in comparison to Lipizzan breed. Acta Agriculturae Scandinavica, Section A - Animal Science, 66, 67 - 74.

Lisáková, B. (2009). Slovakia - the countryside of majestic horses. In Farmer, vol. 17, Land Press Bratislava, p. 28 - 31.

Lukáč, M. (2010). Horses. Svojtka \& Co., Bratislava.

Nei, M., Tajima, F., Tateno, Y. (1983). Accuracy of estimated phylogenetic trees from molecular data. II. Gene frequency data. Journal of Molecular Evolution, 19, 153 170.

Peakall, R., Smouse, P. E. (2012). GenAlEx 6.5: genetic analysis in Excel. Population genetic software for teaching and research-an update. Bioinformatics, 28, 2537 2539.

Petersen, J.L., Mickelson, J.R., Cothran, E.G., Andersson, L.S., Axelsson, J., Bailey, E., Bannasch, D., Binns, M.M., Borges, A.S., Brama, P., da Câmara Machado, A., Distl, O., Felicetti, M., Fox-Clipsham, L., Graves, K.T., Guérin, G., Haase, B., Hasegawa, T., Hemmann, K., Hill, E.W., Leeb, T., Lindgren, G., Lohi, H., Lopes, M.S., McGivney, B.A., Mikko, S., Orr, N., Penedo, M.C., Piercy, R.J., Raekallio, M., Rieder, S., Røed, K.H., Silvestrelli, M., Swinburne, J., Tozaki, T., Vaudin, M., Wade, C., McCue, M.E. (2013). Genetic diversity in the modern horse illustrated from genome-wide SNP data. PLoS One, 8, e54997.

Pjontek, J., Kadlečík, O., Kasarda, R., Horný, M. (2010). Pedigree analysis in four Slovak endangered horse breeds. Czech Journal of Animal Science, 57, 54 - 64.

Rukavina, D., Hasanbašić, D., Pojskić, N., Ramić, J., Zahirović, A., Ajanović, A., Beganović, K., Durmić-Pašić, A. (2015). Analysis of genetic diversity among certain horse breeds from Bosnia and Herzegovina. Veterinaria, 64, 25 - 29.

Vostrý, L., Vostrá Vydrová, H., Hofmanová, B., Veselá, Z., Majzlík, I. (2015). Genetic diversity in Czech Haflinger horses. Poljoprivreda, 21, 163 - 165.

Weir, B. S., Cockerham, C. C. (1984). Estimating F-statistics for the analysis of population structure. Evolution, 38, 1358 - 1370.

ZCHKS (2017). Statute of the Nonius Stud book. Zväz chovatel'ov koní na Slovensku družstvo, Topol'čianky.

Zöldág, L. (2008). Veterinary Genetics and Animal Breeding. A/3 Ltd., Budapest. 